Review article

https://www.journal-imab-bg.org

\title{
TOWARDS ACTIVATION OF THE EMPATHIC RE- SOURCES DURING TERMINAL CARE - AN ART AND/OR A NECESSITY?
}

\author{
Vanina Mihaylova ${ }^{1,2}$, Mariana Liochkova ${ }^{2}$ Iliya Bivolarski ${ }^{3}$, Miglena \\ Tarnovska ${ }^{2}$, Dimitar Shopov ${ }^{4}$, Adolf Alakidi ${ }^{5}$ \\ 1) Department of Physiotherapy, Faculty of Public Health, Medical University \\ Sofia, Bulgaria \\ 2) Department of Healthcare Management, Faculty of Public Health, Medical \\ University Plovdiv, Bulgaria \\ 3) Department of General and Clinical Pathology and Forensic Medicine, Medi- \\ cine Faculty, Medical University, Plovdiv, Bulgaria \\ 4) Department Health Management and Economy of Health, Faculty of Public \\ Health, Medical University, Plovdiv, Bulgaria \\ 5) Department of Epidemiology and Hygiene, Faculty of Medicine, Medical \\ University of Sofia, Bulgaria.
}

\begin{abstract}
:
A brief historical-analytical review of the origin, essence, and development of empathy has been made. The theoretical measurements in the study of the empathic ability are subject to special attention. On the basis of topical definitions of the concept, the application of the approach in different spheres of life, and more specifically in medical practice, has been discussed. The types of communicative behavior in primary medical practice have been differentiated. A theoretical, applied method of communication intervention within the framework of operationalization and scaling of the empathic interaction is proposed. On the basis of the assumption of a genetically determined property of co-experience, the preconditions for the establishment of optimal interpersonal context upon exchange of information between the physician and the patient and making medical decisions have been outlined.

Led by the so systematized and analyzed models and considering the specification of the transformed and activated empathic resources in cases of terminal conditions, an attempt has been made for the presentation of an extensive type of empathic interaction, applied in palliative medicine. The outlining of key messages in cases of terminal conditions in the specified model is complex and at the same time an open, dynamic process, requiring adaptation and enrichment with parameters of religious, ethnical and social nature, and other factors of psychological, spiritual and bio-ethical type in the complex interactive space of palliative medicine.
\end{abstract}

Keywords: empathic interaction, co-experience, palliative medicine, terminal conditions,
It is a general opinion that empathy is the ability of man to experience together with the emotion, feelings and thoughts of another person. It is part of emotional intelligence.

Here are some topical „extreme“ definitions of empathy:

According to Paul Ekman (2007) [1], the concept of empathy does not relate to compassion or pity; it refers to a reaction, a response to other person's emotions. The author differentiates cognitive and emotional empathy: the cognitive one tells how the other person feels and what they might be thinking; the emotional empathy clarifies how the other person feels.

Theodor Lips (1902) designates empathy as an intrapshychic process. It traces the thesis of human compulsion for movement imitation and induces the desire to help the other (under Jürgen Körner,1998) [2].

Leonardo Badea (2010) [3] determines empathy as an ability that is decisive for the success in all spheres of life. The individuals, mostly managers with outlined empathic abilities, have better personal relationships and are able to motivate themselves and others more successfully; they learn faster and enjoy much trust.

According to Laurence, EJ et al. (2004) and Elizabeth Segal (2011) and Bratisis T, and Ziannas P. (2015) et al. [4-8], three forms of empathy may be considered: emotional (affectionate) $\boldsymbol{E} \boldsymbol{E}$, cognitive $\boldsymbol{C E}$ and social empathy $\mathbf{S E}$.

- EE is the ability to identify/experience the feelings of other persons (compassion), also called emotional sensitivity.

- CE is comparable with the "Theory of mind"; this is the ability to realize not only the feelings but also the thoughts and intentions of other persons and on these grounds to make conclusions regarding their behaviour; 
to see the world through the eyes of the others. CE is a correspondence of two minds, which gives us the psychological feeling of the other person's way of thinking.

- SE relates to the understanding of complex social

Table 1. Application of empathy in some spheres of life situations of individuals from different cultures, character features and values, a precondition for the establishment of constructive communication relations.

\begin{tabular}{l|l}
\hline \multicolumn{1}{c}{ Spheres } & $\begin{array}{l}\text { Interactivity } \\
\text { Impact and transfer of the temper from the patient to the therapist. An opportunity is } \\
\text { created for joint experiencing the patient»s emotions and temper for the purpose of their } \\
\text { better perception. There is an active process of common perception. } \\
\text { Its objective is to distract the generally misleading, burdening emotions of the pa- } \\
\text { tient, their suppression and elimination. }\end{array}$
\end{tabular}

Strategy: Therapist's behaviour: A corrective role and behaviour is assumed for the purpose of realistic evaluation of the burdening emotions and introduction of efficient therapeutic approaches.

Motivation, involvement and the desire for the cooperation of the team members have

- Management a leading role. The motives and impulse of the subordinated individuals may not be immediately observed: they may only be outlined through the empathic abilities of the manager. Prevalence of the grounds of unconscious nature subject to change, depending on the situation.

Strategy: The subordinated individuals may be motivated, or demotivation may be prevented if they are perceived not only rationally but also compassionately. Empathy, in this case, is assumed as the main component of the management competency.

\begin{tabular}{l|l} 
- Marketing & $\begin{array}{l}\text { The associates should ,fit in“, carry away to the mental and sensual world of the cli- } \\
\text { ent and to propose adequate but also inexplicit reasons and wishes, a method of a fa- } \\
\text { vourable outcome of the procedure. }\end{array}$
\end{tabular}

Strategy: For the manager, empathy is a significant precondition for an efficient conduct of the commercial process and the development of the business competence of the company.

The emotional intelligence and the related key concepts of self-regulation and well-being are preconditions of the empathic resource of the manager and of the therapist in particular, as well as an important precondition for its therapeutic impact or results, respectively.

The multiple and ambivalent definitions of empathy as a constructive element presuppose the compilation of validated models, a basis of effective and reliable measurements of empathy. Psychological approaches and research tests have been proposed, the most specific for application in palliative medicine being the so-called Interpersonal Reactivity Index of Mark Davis (1983)[9], consisting of four scales:

Four-scale system of studying empathy

-A) For determination of the ability for fitting in, as an actor in fictitious situations and their adequate roleplay' $\rightarrow$ Fantasy Scale.

- B) For determination of the ability for understanding another individual's point of view, i.e. to perceive the world "through his eyes", $\rightarrow$ Perspective Thinking (cognitive empathy).

- C) For determination of sympathy for others and the ability to "build in" his feelings' $\rightarrow$ Empathic Concern (emotional empathy).
- D) For determination of the personal/individual vulnerability of persons in emotionally burdening situations and misfortunes ' $\rightarrow$ Personal distress.

For determination of the ability for empathy as a key competence and its measurement as a synthetic method consisting of 20 other tools, is ,Toronto Empathy Questionnaire" proposed by Nathan Spreng et al. (2009) [10]. The first step to a new definition of empathy is considered to be the acquisition and training of the empathic ability. In accordance with this perception, empathy may be studied in five trends:

- Correct revealing of non-verbal messages

- Experiencing emotions identical to those of other individuals

- Experiencing similar thoughts and memories

- Revealing similar physiological reactions (pulse frequency, stiffness, depression, moist palms, etc.)

- Revealing supportive or encouraging impulses for counteraction.

Within the frameworks of the topical empirical studies in the mid 60s, the communication phenomenon between physician and patient comes to the front, occupying a central position among the scientific studies in this field [11-14]. 
The competencies of the patient, deprived of permanent control, observations and management by the specialist in charge, are dominantly centered and should be used and provoked by the physician.

Regarding the significant preconditions of the interrelation physician-patient, a long-term consensus is dominant in literature [15-17].

Three preconditions are outlined:

$>$ Creation and establishment of optimum interpersonal context

$>$ Information exchange

Table 2. Types of communication behaviour in PMA

\section{> Making a medicinal decision}

The interrelations physician-patient are assumed as a method of a virtual reproduction of the aggregate models of human relations of patients and the knowledge of the physician of the conflict condition and psychodynamics of the sick individual.

With a view to studying the styles of interactive communication between physician-patient, audio records of 573 patients and 127 physicians have been traced, and on this basis, the following types of behaviour have been outlined (Roter et al., 1997)[18].

\begin{tabular}{|l|l|}
\hline \multicolumn{1}{|c|}{ Types } & \multicolumn{1}{|c|}{ Features } \\
\hline 1. Narrowed biomedical communication model & $\begin{array}{c}\text { Characterized by biomedical topics and multiple } \\
\text { closed questions (in 32\% of the conversations) }\end{array}$ \\
\hline 2. Expanded biomedical communication model & $\begin{array}{c}\text { Corresponds to a large extent to the first model, but } \\
\text { fits into a certain degree psychosocial discussion topics } \\
\text { (in 33\% of the conversations) }\end{array}$ \\
\hline 3. Biopsychosocial communication model & $\begin{array}{c}\text { There is an equilibrium between the discussed } \\
\text { biosocial and psychosocial topics (in 20\% of the conver- } \\
\text { sations) }\end{array}$ \\
\hline 4. Psychosocial communication style & $\begin{array}{c}\text { The psycho-social topic prevails in the verbal ex- } \\
\text { change (in 8\% of the conversations) }\end{array}$ \\
\hline 5. Consumption-oriented communication style & $\begin{array}{c}\text { Primarily the patient poses questions and the physi- } \\
\text { cian provides information (in 8\% of the conversations) }\end{array}$ \\
\hline
\end{tabular}

A considerable contribution to this sphere has been outlined in the dissertation thesis of Ch. Rebensburg (2009)[19], dedicated to the empathic interactivity in the ambulatory admission of general practitioners in the diagnostics of mental and psychological diseases.

The analysis of interactivity depending on the participant»s satisfaction shows a maximum degree of patient satisfaction in type 4 and in physicians - in type 5 .
The results correspond to the general opinion that empathy is a response to the physical or mental suffering, and it appears as a reason for recreation of the other person»s individuality.

Within the palliative medicine, empathic interactivity proves to be a key component for mastering the psychoemotional reactions in the management of the negative prognostic truth [20].

Table 3. Empathic interactivity - resources for activation in palliative medicine

\begin{tabular}{|l|l|l|}
\hline \multicolumn{2}{|c|}{ PATIENT } & \multicolumn{1}{c|}{ THERAPIST } \\
\hline \multicolumn{1}{|c|}{ PHASES } & \multicolumn{1}{|c|}{ STAGES } \\
\hline $\begin{array}{l}\text { I. BAD NEWS } \\
\text { psychoemotimmediate } \\
\text { reactions } \\
\text { - Negation }\end{array}$ & $\begin{array}{l}\text { „it cant be true"; } \\
\text { bad joke, unintentional delusion; } \\
\text { change of results } \\
\text { contemplation: health and illness; } \\
\text { life and death; everlasting life balance, } \\
\text { - Isolation }\end{array}$ & $\begin{array}{l}\text { - a six-staged protocol of communicating bad news; } \\
\text { (under Robert Buckman, 1992) [21,22] }\end{array}$ \\
- Seldom shock & $\begin{array}{l}\text { aleness, sweating, tremor, lack of } \\
\text { orientation and self-control, stupor }\end{array}$ & $\begin{array}{l}\text { - resistant defence and resilience } \\
\text { - should not nourish unrealistic hope }\end{array}$ \\
\hline
\end{tabular}




\begin{tabular}{|c|c|c|}
\hline - Anger, outrage & $\begin{array}{l}\text { a succession of aggressive accusations } \\
\text { and inconsolable crying; „why me?“, } \\
\text { „punished without guilt“", ,sin offering“; } \\
\text { envy, anger towards the living; refusing } \\
\text { own responsibility for bad habits }\end{array}$ & $\begin{array}{l}\text { giving an expression of emotions - ,emotional } \\
\text { valve“, „outlet“; } \\
\text { - without opposition to aggression - it should be } \\
\text { put up with in order to prevent blocking of infor- } \\
\text { mation processing; } \\
\text { - possibility for stress decomposition }\end{array}$ \\
\hline $\begin{array}{l}\text { II. NEGOTIATIONS - } \\
\text { DEAL }\end{array}$ & $\begin{array}{l}\text { „double-entry”; expecting an award for } \\
\text { good behaviour; } \\
\text { deferral of death; building a „protective } \\
\text { wall“ of hope }\end{array}$ & $\begin{array}{l}\text { - Should not categorically destroy the protective } \\
\text { „valve“ against the invasion of despair; } \\
\text { - progressive disillusionment; the correct measure } \\
\text { between the „productive lie“ and the „,destruc- } \\
\text { tive truth“ }\end{array}$ \\
\hline III. DEPRESSION & $\begin{array}{l}\text { Grief and sorrow for the passing life; } \\
\text { shares, discusses and orders - more } \\
\text { seldom; the discrepancy between the } \\
\text { expectations of the patient and his } \\
\text { family for the outcome - sometimes } \\
\text { parallel }\end{array}$ & $\begin{array}{l}\text { - Considering not only the grey but also the bright } \\
\text { sides of existence; } \\
\text { - „the life of the relatives will follow its ordinary } \\
\text { course“ - examples } \\
\text { - sharing of pain } \\
\text { - the patient should be able to grieve } \\
\text { - intervention in the conflict patient - family }\end{array}$ \\
\hline IV.ACCEPTANCE & $\begin{array}{l}\text { The calm expectation of the coming end; } \\
\text { fatigue, exhaustion, consent, lack of } \\
\text { feelings or emotions; awareness of } \\
\text { terminated struggle; reorientation of the } \\
\text { values of life; philosophic view of } \\
\text { unrealized ambitions; active reorienta- } \\
\text { tion towards feasible goals; alienation; } \\
\text { elimination of negative thoughts; a } \\
\text { strategy of forgiveness;spiritual } \\
\text { improvement }\end{array}$ & $\begin{array}{l}\text { - Accompanying in the process of dying; } \\
\text { - } \quad \text { hospice program; } \\
\text { - } \quad \text { death with dignity; } \\
\text { - the care is directed towards the family }\end{array}$ \\
\hline
\end{tabular}

It is evident that the exchange of negative information is a significant and complex intervention approach to the communication between the patient and the physician. The process of provision of negative prognostic information requires not only communicative competencies but also well-measured reaction towards the needs and the emotional condition of the patient and adequate correlation to the physician's own feelings and ideas. There is always the dilemma of inspiring hope where it does not exist any more.

In the current pandemic of COVID-19 and a situation of considerable fear, anxiety and insecurity, the use of telemedicine allows not to interrupt the communication between the healthcare professional and the patient, in the expression of empathy and compassion [23]. The introduction of information and communication technologies in mental health care can improve the current provision of compassionate care and create new ways to provide compassion [24].

\section{CONCLUSION:}

Proceeding from the systematized and analysed models and considering the specification of the transformed interactivity in cases of terminal conditions, a successful attempt has been made for the presentation of an extended type of activation of the empathic interactivity, applicable in palliative medicine.

The differentiation of key messages in cases of terminal conditions in the so presented model is a complex and at the same time open dynamic process requiring adaptation and enrichment with parameters of religious, ethnic and social nature, as well as other factors of psychological, spiritual and bioethical nature, within the complex interactive space of palliative medicine. 


\section{REFERENCES:}

1. Ekman P. [Gefühle lesen. Wie Sie Emotionen erkennen und richtig interpretieren.] [in German]. SpringerVerlag Berlin Heidelberg. 2010. [Internet]

2. Körner J. Einfühlung: Über Empathie. Forum Psychoanal. 1998 Mar 1;14(1):1-17. [Crossref]

3. Badea L, Pana NA. The Role of Empathy in Developing the Leader's Emotional Intelligence. Theoretical \& Applied Economics. 2010 Feb 1;17(2543):69-78. [Internet]

4. Lawrence EJ, Shaw P, Baker D, Baron-Cohen S, David AS. Measuring empathy: reliability and validity of the Empathy Quotient. Psychol Med. 2004 Jul;34(5):911-9. [PubMed] [Crossref]

5. Segal EA. Social empathy: A model built on empathy, contextual understanding, and social responsibility that promotes social justice. J Soc Serv Res. 2011 Apr 29;37(3):266-77. [Crossref]

6. Bratitsis T, Ziannas P. From Early Childhood to Special Education: Interactive Digital Storytelling as a Coaching Approach for Fostering Social Empathy. Procedia Comput Sci. 2015; 67:232-240. [Crossref]

7. Bratitsis T, Bardanika P, Ioannou M. Science education and augmented reality content: the case of the water circle. In: 2017 IEEE 17th International Conference on Advanced Learning Technologies (ICALT) 2017 Jul 3. pp. 485-489. [Crossref]

8. Kilova K. Studying the style of learning in bachelor's and master's programs after graduating from the Medical University of Plovdiv using the David Kolb's method. Int J Advan Sci Engin Technol. 2019; 7(Iss-1, Spl. Iss2): 25-27. [Internet]
9. Davis MH. Measuring individual differences in empathy: Evidence for a multidimensional approach. J Pers Soc Psychol. 1983 Jan;44(1):113-126. [Crossref]

10. Spreng RN, McKinnon MC, Mar RA, Levine B. The Toronto Empathy Questionnaire: Scale development and initial validation of a factor-analytic solution to multiple empathy measures. J Pers Assess. 2009 Jan;91(1):62-71. [PubMed] [Crossref]

11. Rogers CR. A Theory of Therapy, Personality, and Interpersonal Relationships: As Developed in the Client-centered Framework. McGraw-Hill. 1959. [Internet]

12. Rogers C. Psychothérapie et relations humaines: Théorie de la thérapie centrée sur la personne. ESF Sciences Humaines; 2016 Nov 21.

13. Wilmer HA. The doctor-patient relationship and the issues of pity, sympathy and empathy. Br J Med Psychol. 1968 Sep;41(3):243-8. [PubMed] [Crossref]

14. Beck RS, Daughtridge R, Sloane PD. Physician-patient communication in the primary care office: a systematic review. J Am Board Fam Pract. 2002 Jan-Feb;15(1):25-38. [PubMed]

15. Schurz M, Radua J, Tholen MG, Maliske L, Margulies DS, Mars RB, et al. Toward a hierarchical model of social cognition: A neuroimaging metaanalysis and integrative review of empathy and theory of mind. Psychological Bulletin. 2020 Nov 5. [PubMed] [Crossref]

16. Shea S, Lionis C. The call for compassion in health care. The Oxford handbook of compassion science. 2017 Sep 26:41-9. [Crossref]
17. Lenton-Brym AP, Moscovitch DA, Vidovic V, Nilsen E, Friedman O. Theory of mind ability in high socially anxious individuals. Anxiety Stress Coping. 2018 Sep 3;31(5):487-99. [PubMed] [Crossref]

18. Roter DL, Stewart M, Putnam SM, Lipkin M. Jr, Stiles W, Inui TS. Communication patterns of primary care physicians. JAMA. 1997 Jan 2229;277(4):350-6. [PubMed]

19. Rebensburg Ch. [Gefuhlsbezogene und empathische Interaktion in der Sprechstunde des Hausarztes und seine Diagnostik psychischer und psychosomatischer Erkrankungen.] [in German] [Dissertation] Medical Faculty of Heinrich-Heine-University Duesseldorf. 2009. [Internet]

20. Mihaylova-Alakidi V. [Negative information during communication with patient - management approaches] Social Medicine Magazine (SocMed, Sofia), Issue 3/2012:55-58. [in Bulgarian]

21. Buckman R, Kason Y. How to Break Bad News: A Guide for Health Care Professionals. 1st Edition. Johns Hopkins University Press. July 1, 1992. [Internet]

22. Kubler-Ross E. Interviews mit sterbenden. Kreuz-Verlag. 1977. [Internet]

23. Kilova K, Uzunova S. Telemedicine in assistance to healthcare in the COVID-19 pandemic. Acta Medica Bulgarica. 2020, 47(4):63-68 [Crossref]

24. Kilova K, Milkov D, Kitova T, Mateva N. Trends in the use of information and communication technologies in the field of healthcare - a literary review. Knowledge - Int J. 2019; 31(4):1181-1187. [Internet]

Please cite this article as: Mihaylova V, Liochkova M, Bivolarski I, Tarnovska M, Shopov D, Alakidi A. Towards Activation Of The Empathic Resources During Terminal Care - An Art And/Or A Necessity? J of IMAB. 2021 JanMar;27(1):3593-33597. DOI: https://doi.org/10.5272/jimab.2021271.3583

Received: 30/12/2019; Published online: 23/02/2021

\section{Address for correspondence:}

Vanina Mihaylova, PhD, Assoc. Prof.

Department of Physiotherapy, Faculty of Public Health, Medical University Sofia, and Department of Healthcare Management, Faculty of Public Health, Medical University Plovdiv, Bulgaria.

E-mail: vanina_delfi@abv.bg 